\title{
The Caregiver Role in Palliative Care: A Systematic Review of the Literature
}

\section{Carla Reigada ${ }^{1 *}$, José Luis Pais-Ribeiro ${ }^{2}$, Anna Novella $\mathrm{S}^{3}$ and Edna Gonçalves ${ }^{4}$}

1SEDA Research Group, Hull York Medical School, University of Hull, United Kindon

${ }^{2}$ Psychology and Educational Sciences College University of Porto, Porto, Portugal

${ }^{3}$ University of Barcelona, Barcelona, Spain

${ }^{4}$ Palliative Care Service, Sao João Hospital Center, Porto, Portugal

\section{Abstract}

Patients nearing the end of their life are daily confronted with complex decisions. Is essential to ensure the continuity of care outside of the health institutions and, in this sense, a presence of a family member at home able to provide multilevel care has become an important goal/resource for patients and health care teams.

Aim: To analyse the literature about roles and tasks of family caregivers of patients in palliative care (PC).

Design: A systematic review of the literature published in English, Portuguese and Spanish between 2006 and 2014 was undertaken, in accordance with the Preferred Reporting Items for Systematic Reviews and Meta-Analyses (PRISMA) guidelines.

Data sources: PubMed, Psyclnfo, Scopus and SciELO were searched to find studies on the family caregiver's role in palliative care.

Results: A total of 13 studies were included and described seven major caregiver roles: to be a caregiver, to be a welfare enhancer, to carry out many tasks, to act as a PC facilitator and be responsible for the continuity of care, to be an apprentice, to be a minimizer/manager of the suffering and to be a decider at the end-of-life.

Conclusions: Family caregivers are still the greatest support of patients in end-of-life especially when they wish to be cared for at home. Carers can be considered the core structure for the continuity of care of these patients. Setting out the various carer tasks and roles will contribute for the "family caregiver" agreement concept as well as, will recognize their value as a person who needs to be cared too.

\section{Introduction}

Caring for someone in a palliative stage is effortlessly understood as a moral duty and family members are the privileged group for this purpose. The palliative care (PC) philosophy argued that this function should be monitored and supported by specialized teams since they are trained and focused on pain relief, including the suffering of the family. However, and although unintentionally, only material benefits at home (e.g. Technical aids), is given to family carers to support them, which can increase their suffering due to their social isolation [1].

Family carers wellbeing mostly depends on the attitudes of the health care teams through their communication, active listening and knowledge. Genuine attitudes as family training and empowering are described in several studies with successful results [2-4]. Defined the "hands on care" as those who provide directly and/or indirectly care for the person with a terminal illness [5]. This study highlighted that this sort of experience allows caregivers to learn with their own experiences and helps to growth in their personal and spiritual matters. However, it can cause negative feelings as well, touching the significance of their own existence [6].

Usually, family caregivers are women, with a mean of 50 years old, spouses and children, which are negatively affected in their quality of life, watching the deterioration of their sick family member $[7,8]$. Nevertheless, studies in this area are mostly focused on cancer patient's caregivers and little is known about the reality of non-cancer patient's family carers.

A systematic review of the literature from 2000 to 2011 sought to meet this challenge by asking caregiver experiences with Amyotrophic Lateral Sclerosis (ALS) patients. A total of 59 articles were studied showing that it is imperative that the caregiver has information about the diagnosis and cognitive-behavioral consequences of this pathology, and that in some moment of the disease trajectory they will be requested to participate in important treatment decisions, such as to receive assisted ventilation. The same review alerted to the fact that most of the studies in this area were focused on the description of the profile of these family carers, instead of focusing on the development of interventions aiming to assist the caregivers to cope with their everyday emotions, instrumental and spiritual issues [9].

Considering that family caregivers ensure the continuity of patient care at home, PC teams should understand the role and tasks of their performance and must be prepared to identify and help them to work out their needs, as well as educate them in activities of care and self-care [10]. With this in mind, we propose to analyze the activities and roles undertaken by family caregivers of patients in PC literature.

\section{Method}

A systematic search of the literature was undertaken between January 2009 to December 2014 using the following combinations of terms (Palliative care [title]) OR Hospice [Title]) OR End-of-

*Corresponding author: Carla Reigada, SEDA Research Group, Hull York Medical School, University of Hull, United Kindon. Tel: 01482463757 E-mail: carla.reigada@hyms.ac.uk

Received September 14, 2015; Accepted October 30, 2015; Published November 07, 2015

Citation: Reigada C, Pais-Ribeiro JL, Novellas A, Gonçalves E (2015) The Caregiver Role in Palliative Care: A Systematic Review of the Literature. Health Care Current Reviews 3: 143. doi: 10.4172/2375-4273.1000143

Copyright: (C) 2015 Reigada C, et al. This is an open-access article distributed under the terms of the Creative Commons Attribution License, which permits unrestricted use, distribution, and reproduction in any medium, provided the original author and source are credited. 
life [Title]) AND Caregivers [Title]) OR family [Title]) AND scroll [Title / Abstract]). Articles in English, Portuguese and Spanish were included. Electronic databases were searched in PubMed, PsycINFO, Scopus and SciELO using the EndNote X7 and Excel software's. Only original articles published in scientific journals were included and the population was selected over 18 years of age. Pediatrics studies, books, doctoral and/or master's degree theses, case studies, and literature reviews were excluded. For evaluating the quality of each article, the Hawker method was used [11]

All articles were selected, analyzed and classified by two independent reviewers according to their quality, and there was a third reviewer for situations of doubt or lack of consensus between the two main reviewers.

\section{Search strategy}

The selection of the articles was made in three moments taking into account the criteria delineated above and based on the research question: What tasks /activities and functions are met by family caregivers of patients in PC?

First, the primary reviewer examined the titles identified in the database, deleted the duplicate ones, and selected those titles considered relevant for the study. Secondly, two independent reviewers analyzed the abstracts flagged by title, and they excluded those that did not seem to answer the research question; the third step included the full reading articles and selection.

\section{Concepts}

This study took into account the following concepts:

Family caregiver/Caregiver's- relatives, friends, neighbors and all those who attend voluntarily the patient daily care [12].

Tasks/Activities - any work, occupation, obligation, utility and other actions that could describe a caregiver experiment in the context of PC.

Role - the set of tasks or activities that defines a sociocultural representation [13].

\section{Type of study}

The classification and quality assessment of the studies was based on an instrument developed by, used for quantitative and qualitative research [11]. This tool allows to classify each article on a scale of 1 to 4 points ( 1 "very poor", 2 "poor", 3 "satisfactory", 4 "good"), evaluating nine distinct parameters: title and abstract, introduction and intent, method and data, sample, data analysis, ethics and bias, results, implications, degeneracy and utility. Adding up the scores resulting from each parameter will result from a value amid 9 to 36 ( 9 "Very poor, 36" Good").

\section{Results}

A total number of 666 papers were identified of which 596 were excluded because of the title and duplicates. Secondly, 70 abstracts were read and, of those, 38 were excluded for not answering the research question. Thus resulting in 32 articles of which 25 were excluded after reading the full article. Six articles were added to this selection due to their relevance (Figure 1).

Hence, this systematic review includes thirteen original articles published from January 2009 to December 2013. Two studies have been conducted in Sweden, one in the United kingdom, one in Thailand, two

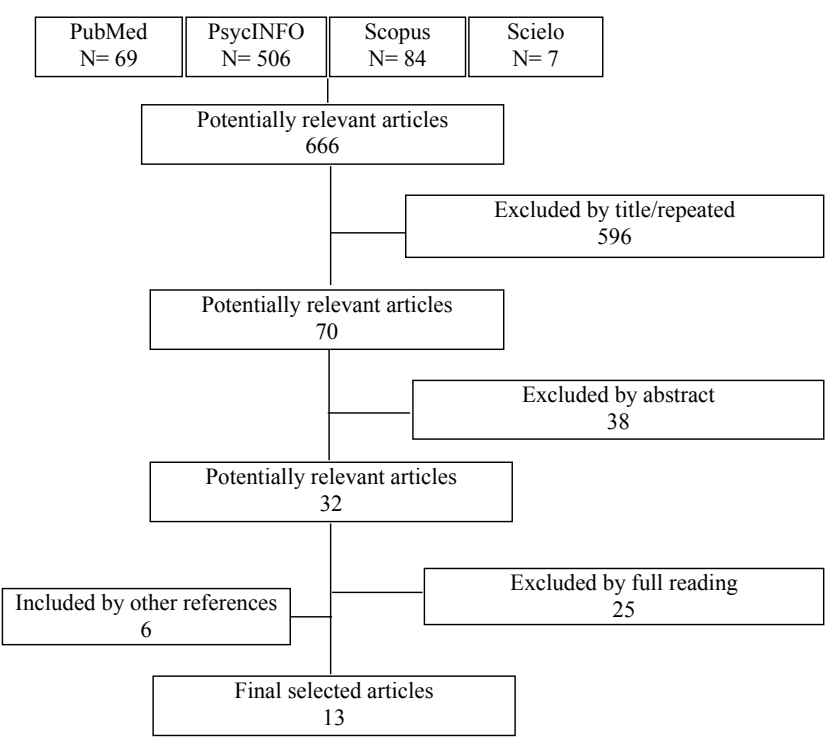

Figure 1: Selection process of the articles (identification, screening, eligibility and inclusion).

in Norway, one in Brazil, two in Australia, two in the United States, one in Taiwan and Canada. Altogether, 13 studies were included in this systematic review adopted qualitative research methods. The majority of the articles was rated as being "good" $(\mathrm{n}=11)$; the other two articles were considered as being "sufficient" The total scores can be seen on Table 1.

all 13 studies include informal caregivers (family or close friends) of patients with severe disease (cancer or not) in palliative condition as participants, followed by teams of PC or Intensive Care units (ICU's). Six studies intended to examine the influence of gender, skills, experiences and needs of carers in their home environment and two studies tried to do it in a hospital setting [6,14-18]. One study reported caregivers experiences with ventilated patients at home, and other showed the evidence of caring for patients with Amyotrophic Lateral Sclerosis (ALS) [12,19].

(Table 1- Included studies: general characteristics $(\mathrm{n}=13)$ - here)

(Table 2- Tasks, activities or family roles description $(n=13)$ - here)

Four studies did not specify the setting of care where the patient was during the data collection $[9,13,16,17,20-22]$, and four did not make reference to the fact that the patient was followed or not by a PC team.

\section{Data Analysis}

The role that each caregiver has in the society and in the family system, integrates different tasks and activities. The analysis of the selected articles originated seven main roles (Table 3 ).

(Table 3 - Palliative Caregivers Role - here)

The caregiver can fill the role of being a "caregiver". They accept the caring as a natural action, presumably imposed by the society and fulfilling a moral obligation. The caregiver also assumes the role of being a "Well-being enhancer" by undertaking the task of keeping the hope of the patient, maintaining the marital relationship, and helping to provide balanced activities to help the family to rest and cope with the situation they are experiencing; providing religious rituals and satisfying the wishes of the patient are also part of this role. 
Citation: Reigada C, Pais-Ribeiro JL, Novellas A, Gonçalves E (2015) The Caregiver Role in Palliative Care: A Systematic Review of the Literature. Health Care Current Reviews 3: 143. doi: 10.4172/2375-4273.1000143

Page 3 of 6

\begin{tabular}{|c|c|c|c|c|c|}
\hline & $\begin{array}{l}1^{\text {st }} \text { Authorl } \\
\text { yearCountry }\end{array}$ & Qualitative Data & Patients & Sample & Q.E. \\
\hline 1 & $\begin{array}{l}\text { Munck, B. (2008) } \\
\text { Sweden }\end{array}$ & $\begin{array}{l}\text { Exploratory, descriptive; semi-structured } \\
\text { interview; } \\
\text { Critical incident }\end{array}$ & $\begin{array}{l}\text { Followed by the domiciliary PC } \\
\text { team, died in unspecified hospital } \\
\text { units }\end{array}$ & $\begin{array}{l}\text { People close to the patient who provided home care, } \\
\text { mourners up to } 18 \text { months }(n=9)\end{array}$ & 34 \\
\hline 2 & $\begin{array}{l}\text { Brazil, K. (2009) } \\
\quad \text { Canada }\end{array}$ & $\begin{array}{l}\text { Descriptive; longitudinal. interview; Barthel } \\
\text { Index; Robinson Caregiver Strain Scale }\end{array}$ & $\begin{array}{l}\text { Terminal illness, with no reference } \\
\text { to the place of care }\end{array}$ & $\begin{array}{l}\text { Spouses, }>50 \text { years, use of community services, social } \\
\text { centers/health }(n=283)\end{array}$ & 36 \\
\hline 3 & $\begin{array}{l}\text { Lau, D.T. (2009) } \\
\quad \text { Chicago }\end{array}$ & $\begin{array}{l}\text { Interview } \\
\text { coding }\end{array}$ & $\begin{array}{l}\geq 60 \text { years with chronic pathology } \\
\text { and receiving support of Hospices } \\
\text { Care Programs }\end{array}$ & $\begin{array}{l}\text { People } \geq 18 \text { years, responsible for managing the } \\
\text { patient's medication at home }(n=23)\end{array}$ & 19 \\
\hline 4 & $\begin{array}{l}\text { Huang, Tzu-Ting } \\
\text { (2010)Taiwan }\end{array}$ & $\begin{array}{l}\text { Grounded theory method } \\
\text { Interview }\end{array}$ & $\begin{array}{l}\text { Patients at end-of-life, ventilator- } \\
\text { dependent in } 3 \mathrm{ICU}\end{array}$ & Main caregivers $>18$ years $(n=23)$ & 30 \\
\hline 5 & $\begin{array}{l}\text { Fratezi, F. (2011) } \\
\text { Brazil }\end{array}$ & Open and semi-structured interview & $\begin{array}{l}\text { Followed by PC homecare } \\
\text { program of a University Hospital }\end{array}$ & Main caregivers $(\mathrm{N}=9)$ & 21 \\
\hline 6 & $\begin{array}{l}\text { Mossin, H. (2011) } \\
\text { Norway }\end{array}$ & $\begin{array}{l}\text { Grounded Theory, with recourse to the audio } \\
\text { recording }\end{array}$ & $\begin{array}{l}\text { Cancer patients who died in } \\
\text { oncology/palliative hospital units }\end{array}$ & $\begin{array}{l}\text { Wives }>20 \text { years grieving } 10 / 15 \text { weeks, who stayed at } \\
\text { the hospital during the patient's hospitalization }(n=8)\end{array}$ & 32 \\
\hline 7 & $\begin{array}{l}\text { Kongsuwan, W. } \\
\text { (2011)Thailand }\end{array}$ & $\begin{array}{l}\text { Audio Interview phenomenological study, } \\
\text { using the recording }\end{array}$ & $\begin{array}{l}\text { Adults deceased at a university } \\
\text { hospital ICU }\end{array}$ & $\begin{array}{l}\text { Thai Buddhist family who accompanied patients at end } \\
\text { of life }(n=9)\end{array}$ & 31 \\
\hline 8 & Harding, R. (2012)UK & $\begin{array}{l}\text { Descriptive, cross-sectional } \\
\text { Semi-structured interview }\end{array}$ & $\begin{array}{l}\text { Cancer patients followed by PC } \\
\text { Community Support Team }\end{array}$ & $\begin{array}{l}\text { Informal carers, } \geq 18 \text { years, who performed unpaid } \\
\text { physical and emotional home care and were identified } \\
\text { by the patient as "primary caregiver" }(n=20)\end{array}$ & 35 \\
\hline 9 & $\begin{array}{l}\text { Milberg, A. (2012) } \\
\text { Sweden }\end{array}$ & $\begin{array}{l}\text { Interview and narrative analysis Discussion } \\
\text { of results in research group }\end{array}$ & $\begin{array}{l}\text { Accompanied by units and teams } \\
\text { who provide PC at home }\end{array}$ & Family caregivers $(n=14)$ & 34 \\
\hline 10 & $\begin{array}{l}\text { Quinn, J.R. (2012) } \\
\text { USA }\end{array}$ & $\begin{array}{l}\text { Prospective study; Ethnographic method } \\
\text { Participant observation and semi-structured } \\
\text { interviews }\end{array}$ & $\begin{array}{l}\text { Patients at end of life, admitted } \\
\text { to ICU }\end{array}$ & $\begin{array}{l}\text { Families, nurses, doctors, other professionals and } \\
\text { patients }(n=138)\end{array}$ & 30 \\
\hline 11 & $\begin{array}{l}\text { Ugalde, A. (2012) } \\
\quad \text { Australia }\end{array}$ & $\begin{array}{l}\text { Symbolic interactionism } \\
\text { Delphi } \\
\text { Semi-structured interview } \\
\text { Grounded theory }\end{array}$ & $\begin{array}{l}\text { Cancer patients receiving } \\
\text { palliative treatment }\end{array}$ & Caregivers identified by patients $(n=17)$ & 32 \\
\hline 12 & $\begin{array}{l}\text { Aoun, S. (2011) } \\
\quad \text { Australia }\end{array}$ & $\begin{array}{l}\text { Exploratory } \\
\text { Questionnaire and interview }\end{array}$ & $\begin{array}{l}\text { Amyotrophic Lateral Sclerosis } \\
\text { patients who were offered PC }\end{array}$ & Bereaved spouses (between 1 and 4 years) $(n=13)$ & 34 \\
\hline \multirow[t]{2}{*}{13} & $\begin{array}{l}\text { Lind, R. (2012) } \\
\quad \text { Norway }\end{array}$ & Interviews narrative analysis & Admitted to ICU & $\begin{array}{l}\geq 18 \text { years who visited the patient daily and } \\
\text { participated in treatment decisions }(n=27)\end{array}$ & 32 \\
\hline & $\begin{array}{c}1^{\text {st }} \text { Autorl } \\
\text { yearCountry }\end{array}$ & Qualitative Data & Patients & Sample & Q.E. \\
\hline 1 & $\begin{array}{l}\text { Munck, B. (2008) } \\
\text { Sweden }\end{array}$ & $\begin{array}{l}\text { Exploratory, descriptive; semi-structured } \\
\text { interview; } \\
\text { Critical incident }\end{array}$ & $\begin{array}{l}\text { Followed by the PC team } \\
\text { domiciliary, died in hospital in } \\
\text { units not specified }\end{array}$ & $\begin{array}{l}\text { People close to the patient who developed home care, } \\
\text { mourners up to } 18 \text { months }(n=9)\end{array}$ & 34 \\
\hline 2 & $\begin{array}{l}\text { Brazil, K. (2009) } \\
\text { Canada }\end{array}$ & $\begin{array}{l}\text { Descriptive; longitudinal. interview; Barthel } \\
\text { Index; Robinson Caregiver Strain Scale }\end{array}$ & $\begin{array}{l}\text { Terminal illness, without reference } \\
\text { to the site of care }\end{array}$ & $\begin{array}{l}\text { Spouses, }>50 \text { years, use of community services, social } \\
\text { centers/health }(n=283)\end{array}$ & 36 \\
\hline 3 & $\begin{array}{l}\text { Lau, D.T. }(2009) \\
\quad \text { Chicago }\end{array}$ & $\begin{array}{l}\text { Interview } \\
\text { coding }\end{array}$ & $\begin{array}{l}\geq 60 \text { years with chronic pathology } \\
\text { and receiving support of Hospices } \\
\text { Care Programs }\end{array}$ & $\begin{array}{l}\text { Person } \geq 18 \text { years, responsible for managing patient } \\
\text { medical home }(n=23)\end{array}$ & 9 \\
\hline 4 & $\begin{array}{l}\text { Huang, Tzu-Ting } \\
\text { (2010)Taiwan }\end{array}$ & $\begin{array}{l}\text { Grounded theory method } \\
\text { Interview }\end{array}$ & $\begin{array}{l}\text { Patients in end-of-life, ventilator- } \\
\text { dependent on } 3 \text { IUC's }\end{array}$ & Main carers $>18$ years $(n=23)$ & 30 \\
\hline 5 & $\begin{array}{l}\text { Fratezi, F. (2011) } \\
\text { Brazil }\end{array}$ & Open and semi-structured interview & $\begin{array}{l}\text { Followed in CP users homecare } \\
\text { program at a University Hospital }\end{array}$ & Main carers $(\mathrm{N}=9)$ & 21 \\
\hline 6 & $\begin{array}{l}\text { Mossin, H. (2011) } \\
\text { Norway }\end{array}$ & $\begin{array}{l}\text { Grounded Theory, with recourse to the audio } \\
\text { recording }\end{array}$ & $\begin{array}{l}\text { Cancer patients who died in } \\
\text { hospital inpatient oncology/ } \\
\text { palliative }\end{array}$ & $\begin{array}{l}\text { Wives }>20 \text { years grieving } 10 / 15 \text { weeks, who spent } \\
\text { time in the hospital during the patient's hospitalization } \\
(n=8)\end{array}$ & 32 \\
\hline 7 & $\begin{array}{l}\text { Kongsuwan, W. } \\
\text { (2011)Thailand }\end{array}$ & $\begin{array}{l}\text { Audio Interview phenomenological study, } \\
\text { using the recording }\end{array}$ & $\begin{array}{l}\text { Deceased adult ICU in a } \\
\text { university hospital }\end{array}$ & $\begin{array}{l}\text { Thai Buddhist family who accompanied patients in end } \\
\text { of life }(n=9)\end{array}$ & 31 \\
\hline 8 & Harding, R. (2012)UK & $\begin{array}{l}\text { Descriptive, cross-sectional } \\
\text { Semi-structured interview }\end{array}$ & $\begin{array}{l}\text { Cancer patients followed by PC } \\
\text { Community Support Team }\end{array}$ & $\begin{array}{l}\text { Informal carers, } \geq 18 \text { years, who performed unpaid } \\
\text { home physical and emotional care and were identified } \\
\text { by the patient as "primary caregiver" }(n=20)\end{array}$ & 35 \\
\hline 9 & $\begin{array}{l}\text { Milberg, A. (2012) } \\
\text { Sweden }\end{array}$ & $\begin{array}{l}\text { Interview and narrative analysis Discussion } \\
\text { of results in research group }\end{array}$ & $\begin{array}{l}\text { Companied by units and teams } \\
\text { who provide PC at home }\end{array}$ & Family caregivers $(n=14)$ & 34 \\
\hline 10 & $\begin{array}{l}\text { Quinn, J.R. (2012) } \\
\text { USA, New York }\end{array}$ & $\begin{array}{l}\text { Ethnographic prospective } \\
\text { Participant observational and semi- } \\
\text { structured interviews }\end{array}$ & $\begin{array}{l}\text { Patients at end of life, admitted } \\
\text { to ICU }\end{array}$ & $\begin{array}{l}\text { Families, nurses, doctors, other professionals and } \\
\text { patients }(n=138)\end{array}$ & 10 \\
\hline 11 & $\begin{array}{l}\text { Ugalde, A. (2012) } \\
\text { Australia }\end{array}$ & $\begin{array}{l}\text { Symbolic interactionism } \\
\text { Delphi } \\
\text { Semi-structured interview } \\
\text { Grounded theory }\end{array}$ & $\begin{array}{l}\text { Cancer patients receiving } \\
\text { palliative treatment }\end{array}$ & $\begin{array}{l}\text { Caregivers assets / current or former patient identified } \\
\text { by> } 3 \text { months of mourning }(n=17)\end{array}$ & 32 \\
\hline 12 & $\begin{array}{l}\text { Aoun, S. (2011) } \\
\quad \text { Australia }\end{array}$ & $\begin{array}{l}\text { Exploratory } \\
\text { Questionnaire and interview }\end{array}$ & $\begin{array}{l}\text { Amyotrophic Lateral Sclerosis } \\
\text { patients who were offered PC }\end{array}$ & Bereaved spouses (between 1 and 4 years) $(n=13)$ & 34 \\
\hline 13 & $\begin{array}{l}\text { Lind, R. (2012) } \\
\quad \text { Norway }\end{array}$ & Interviews narrative analysis & Admitted to ICU's & $\begin{array}{l}\geq 18 \text { years who visited daily patient and participated in } \\
\text { the decision of treatment }(n=27)\end{array}$ & 32 \\
\hline
\end{tabular}

*Quality Evaluating (Q.E.) of each article, Hawker et al. (2002)

Table 1; Included studies: general characteristics $(n=13)$. 
Citation: Reigada C, Pais-Ribeiro JL, Novellas A, Gonçalves E (2015) The Caregiver Role in Palliative Care: A Systematic Review of the Literature. Health Care Current Reviews 3: 143. doi: 10.4172/2375-4273.1000143

Table 2: Tasks, activities or family roles description ( $\mathrm{N}=13)$

To be available day and night ( 24 hours/day); To keep the patient's hope up; To be physically and mentally available 24 hours a day; To not lose control; To satisfy

1 the patient's desires; To be responsible for the patient; To be a pillar of the patient's intensive care; To transport the patient to appointments; Troubleshoot nutrition and evacuation problems of the patient.

2 Attending to the patient's hygiene care; Naturally assume the caregiving role socially imposed (caregiving role).

3 Manage medication (buy, organize, administer); Speak with the health care team, providing specific information; ability to detect signs and symptoms; know the different drugs (main and side effects, how to administer); knowledge about opioids; interpret the patient's condition;

Caregiving as a dynamic process; Emotional and cognitive care; Learn to deal with fan, monitor and other technical aids; responsibility to care; To control; have clinical information; care of the patient-caregiver; assume the role of doctor, nurse, therapist; forced to care;

5 To provide care due to moral obligation; Learn about caregiving procedures; Dealing with grief; To help (to provide a helping relationship); To assist the patient in the dying process.

6 Maintain the marital relationship; To be with the patient in the hospital; Support the patient; Ensure household chores; To be present; Support the rest of the family. Promote physical, psychological and spiritual care; Attend for a peaceful death; Take treatment decisions in end of life; Give and receive care with compassion;

7 Attend and reduce the patient's suffering; Provide religious rituals; Care for the remaining members of the family; Provide emotional support to the patient and rest

of the family; Promote a good relationship; Show empathy and understanding; Continue to work while providing care; Touch, share emotions and endure; Have an obligation to make decisions; Be present at the hospital where the patient is staying; Bathe the patient; Massage the patient; Converse with the patient; Pray.

8 Be prepared in order to provide the best care possible; Support relatives and friends; live with uncertainty.

9 Face illness alongside the patient; Give medications; Decide when to contact the team or assume responsibility for the moment; Directly involved in patient care and support; Be informed; Participate in patient comfort.

10 Assume the role of primary caregivers; Participate in decision making; Spokesperson of the family; Attend to the patient's wishes; protect vulnerable members;

"Experts" on health care.

11 To be able to influence; strengthen relationships; articulate different tasks; Housekeeping; assume the responsibility for caregiving; help the patient have a social life; "Is like having a job".

12 Caregiving day to day; Do several practical activities; Be attentive to emotional aspects; Manage medication, prepare meals, bathe, shave; support during night time; Assume the functions of nurses; work while caregiving; have more responsibilities; Meet the patients' physical and psychological needs;

Participate in decision making at end of life; maintain a healthy relationship with the patient; protect the patient; be close to the patient; be informed; communicate

13 with the team; manage the relationship between patient-family-staff; repeat/convey information to the patient; promote patient autonomy in decision-making; Share decisions with the patient;

Table 3: Palliative Caregivers Role.

\section{Tasks / Activities}

Naturally assume the caregiving role socially imposed (caregiving role)

Caregiving as a moral obligation

To be prepared to provide care in the best way possible

To be available 24 hours / day

To keep the patient's hope up

To satisfy the patient's wishes

To help (providing a helping relationship)

To maintain the marital relationship

To support the remaining family

To provide religious rituals

To participate in patient comfort

To transport the patient to appointment

Troubleshoot nutrition and evacuation problems of the patient

Attending to the patient's hygiene care

To be with the patient at the hospital

To ensure household tasks

To continue to work while providing care

Massage the patient

To provide and manage medication

To cope with the patient's suffering

To play and share emotions

To talk with the patient

To pray

To assist in the dying process

To have empathy and be understanding

Presence

To give and receive compassionate care

Living with uncertainty

To face illness alongside the patient

To be a pillar of intensive support for the patien

To not lose control

Learn ways to provide care

To assume responsibility for the patien

To participate in decision-making processes, including end-of-life decisions

To be informed

"Handyman"

Well-being Enhancer

Role

Caregiver

Minimizer / Manager of suffering

PC facilitator and responsible for the continuity of care

Learner

Decision-maker at the end-of-life 
To the extent that the family caregiver performs multiple activities over 24 hours / 7 days a week, consecutively or not, they undertake the role of being a "Diversity of tasks' fulfiller" (e.g. Transferring the patient to medical appointments, doing hygiene care, ensuring housekeeping, massage, managing and administering medication).

Being 24 hours a day with the patient require that caregivers are be physically and mentally available. During this time the caregiver is enforced to deal with grief and often takes the role of a "Minimizer/ Manager of suffering", sharing emotions, showing empathy and understanding, praying, talking to the patient, helping the patientto deal with the end of life experience and dying peacefully.

Another role of the caregiver is to be a "PC facilitator and responsible for the continuity of care". Taking the patient disease along and being present, applying and receiving compassionate care, reflects that the career is undoubtedly the pillar of patient security. This is why the family carers is often seen as part of the health care team.

In several studies, the role of the family caregiver was associated with decision-making, assuming the role of "Decider at the end-of-life". This role incites a sense of obligation and at the same time, a feeling of anguish, particularly when these decisions refer to medical decisions.

\section{Discussion}

The unexpected presence of the disease within a family is responsible for the outbreak of new occupations and concerns that profoundly affect the family. Furthermore, many governments, health schemes, and social institutions just offer a little support to family caregivers increasing the suffering and burden caused by such situations [4]. Therefore, health professionals, particularly PC teams, have to be aware of the many tasks and activities assumed by the family and informal caregivers at end of life in order to minimize the physical and emotional burden they often face.

Socially assigned and intrinsically assumed, the function of the family "caregiver" is mostly understood as a voluntary and not tax job [23]. However, sometimes family carers take care of their ill relatives due to moral obligation and their beliefs of being ready and capable of doing their best $[6,10]$. Reported that $90 \%$ of the care of dependent patients are provided by family carers and this means being available day and night (24 hours/day), supporting the patient, meeting and reducing their suffering $[16,23]$. The primary caregiver, who is normally the nearest person, usually provides physical, psychological, social and spiritual care, aiming to promote the well-being of the patient, relatives and friends, allowing the patient to be cared for at home, and also contributing to cost reduction in health $[3,15]$. In the articles included in this systematic review, some caregivers who were not supported by health care teams often lost control of the situation, which was perceived as a negative experience [23]. Other studies reported gender differences caregiving role. "Caregiving role", Female carers tend to have more burnout levels and receiving less assistance from other family members. This should remind PC teams that more focus o this population is needed. It is known that PC support promote a sense of security and harmony in the continuity of care [14,17]. When this spirit of confidence is underpinned, a sense of self-protection reappears, because it is related to variables such as the ability to keep the patient at home, caregiver recognition, sharing responsibility, sense of belonging to a group with common values and the fact that they holds the necessary data.

Conflicts between family members and health care teams have been reported as a result from communication problems and disagreements on the way the patient is monitored and symptom control is ensured. Nevertheless, both the family caregivers as the health care teams seem to share the same values [24]. Many professionals working in PC are still not prepared to implement strategies for effective intervention in this area, perhaps because of the lack of training and research on interventions focused on family caregivers, as well as due to the fact that working families who simultaneously assume the role of providing informal care are still not seen as a priority [3]. The clinical team should enhance the emotional stability of the family, understand the beliefs of each member of the family, and devise appropriate and customized strategies when they want to transmit information. The implementation of good practices and the involvement of the family in the care plan is a crucial reason why information and clarification of medical decisions should be done properly [24]. Thus, it is relevant that the families get timely information that will help them to care and assume the role of participating in the care planning and provision, feeling part of the health care team [18].

This literature review also shows the importance of sharing hard decisions as a relevant matter in this field, both for the health care teams as for the families. The role of "decision-making" that is being assumed and/or assigned by the caregiver's, results from daily tasks such as deciding when to contact the team, as well as they can refer to more complex and difficult situations such as those related to end of life treatments. Caregivers can act as surrogates in the decisionmaking processes and support conversations and interactions between the patient and the physicians. If the family caregivers are the partners or spouses of the patient, they can also help the patient to cope with the disease by addressing the physical, emotional and financial needs, maximizing the quality of life of the patient, managing the complex care and contributing to decrease hospital/institutional admissions [10] Considering all these aspects, family caregivers are often considered by the health care teams as "overall tasks' performers" [10,15,18,21]

Although, it is known that cultural factors can determine the concepts of physical, spiritual and psychological maintenance, It is universally admitted that patients have three basic needs: security; integrity and sense of life; sense of belonging [25]. Most part of these needs can be suppressed by family carers, especially because of the intimacy in the relationship shared with the patient. Everything will depend along the feeling of love and the quality of the relationship established between the patient, the caregiver, and the PC team.

\section{Conclusion}

A concrete knowledge about the actions done by caregivers can facilitate good clinical and psychosocial practices, in particular in the context of PC where the family simultaneously provides and receives health care.

For the well-being of the patients, the caregivers perform distinct activities added to those they have in their own personal routine (Table 3 ), which is essential for the continuity of care of the patient at the end of life, both at the hospital as at home. This systematic review has shown that although universally recognized, the role of the family caregiver is still poorly supported by society, health teams and family systems.

Family members who are close to the patient may play the role of caregiver, well-being enhancer, diversity of tasks' fulfiller, minimizer and managing suffering (patient and himself), PC facilitator and responsible for the continuity of care, apprentice and participant of health teams. They also play the role of controller because they often have to take decisions, although the sick person concern and not to 
Citation: Reigada C, Pais-Ribeiro JL, Novellas A, Gonçalves E (2015) The Caregiver Role in Palliative Care: A Systematic Review of the Literature. Health Care Current Reviews 3: 143. doi: 10.4172/2375-4273.1000143

Page 6 of 6

themselves. Much work remains to be done in the area of carers empowerment. PC teams can take an essential role since it is the primary objective of their work to promote suffering relief to patient and carers [26].

\section{Acknowledgments}

The authors would like to thank to Dr. Sandra Martins and Mr. Luís Barata Feio for the contribution in this paper.

Study sponsored by the Isabel Levy

Research Grant, of the Portuguese Association of Palliative Care.

\section{References}

1. Twigg J (1989) Models of carers: how do social care agencies conceptualise their relationship with informal carers? J Soc Policy 18: 53-66.

2. Andershed B (2006) Relatives in end-of-life care--part 1: a systematic review of the literature the five last years, January 1999-February 2004. J Clin Nurs 15: $1158-1169$

3. Hudson P, Payne S (2011) Family caregivers and palliative care: current status and agenda for the future. J Palliat Med 14: 864-869.

4. Payne S, Grande G (2013) Towards better support for family carers: a richer understanding. Palliat Med 27: 579-580.

5. Burns CM, Abernethy AP, Dal Grande E, Currow DC (2013) Uncovering an invisible network of direct caregivers at the end of life: a population study. Pallia Med 27: 608-615.

6. Fratezi FR, Gutierrez BA (2011) [Family caregiver of elderly patients in palliative care: the process of dying at home]. Cien Saude Colet 16: 3241-3248.

7. Luxardo N, Tripodoro V, Funes M, Berenguer C, Nastasi R, et al. (2009) [Caregivers of palliative care home patients]. Medicina (B Aires) 69: 519-525.

8. Reigada C, Ribeiro E, Novellas A (2010) Capacidades familiares para cuidar de enfermos oncológicos paliativos un estudio cualitativo. Medicina Paliativa 2:1-8.

9. Aoun SM, Bentley B, Funk L (2012) A 10-year literature review of family caregiving for motor neurone disease: Moving from caregiver burden studies to palliative care interventions. Palliative Medicine, 27: 437- 446.

10. Mitnick S, Leffler C, Hood VL; American College of Physicians Ethics Professionalism and Human Rights Committee (2010) Family caregivers patients and physicians: ethical guidance to optimize relationships. J Gen Intern Med 25: 255-260.

11. Hawker S, Payne S, Kerr C, Hardey M, Powell J (2002) Appraising the evidence: reviewing disparate data systematically. Qual Health Res 12: 1284-1299.

12. Huang TT, Peng JM (2010) Role adaptation of family caregivers for ventilator- dependent patients: transition from respiratory care ward to home. $\mathrm{J}$ Clin Nurs 19: 1686-1694

13. Haslam SA (2014) Making good theory practical: five lessons for an Applied Social Identity Approach to challenges of organizational, health, and clinical psychology. Br J Soc Psychol 53: 1-20.

14. Brazil K, Thabane L, Foster G, Bédard M (2009) Gender differences among Canadian spousal caregivers at the end of life. Health Soc Care Community 17: $159-166$

15. Harding R, Epiphaniou E, Hamilton D (2012) What are the perceived needs and challenges of informal caregivers in home cancer palliative care? Qualitative data to construct a feasible psycho-educational intervention. Support Care Cancer, 20:1975-1982.

16. Kongsuwan W, Chaipetch $O$ (2011) Thai Buddhists' experiences caring for family members who died a peaceful death in intensive care. Int J Palliat Nurs 17: 329-336.

17. Lind R, Nortvedt P, Lorem G, Hevrøy O (2013) Family involvement in the endof-life decisions of competent intensive care patients. Nurs Ethics 20: 61-71.

18. Milberg, A., Wåhlberg, R., Jakobsson, M., et al. (2012). What is a 'secure base' when death is approaching? A study applying attachment theory to adult patients' and family members' experiences of palliative home care. PsychoOncology, 21, 886-895.

19. Quinn JR, Schmitt M, Baggs JG, Norton SA, Dombeck MT, et al. (2012) Family members' informal roles in end-of-life decision making in adult intensive care units. Am J Crit Care 21: 43-51.

20. Lau DT, Kasper JD, Hauser JM, Berdes C, Chang CH, et al. (2009) Family caregiver skills in medication management for hospice patients: a qualitative study to define a construct. J Gerontol B Psychol Sci Soc Sci 64: 799-807.

21. Ugalde A, Krishnasamy $M$, Schofield $P$ (2012) Role recognition and changes to self-identity in family caregivers of people with advanced cancer: a qualitative study. Support Care Cancer 20: 1175-1181.

22. Mossin $\mathrm{H}$, Landmark BT (2011) Being present in hospital when the patient is dying - a grounded theory study of spouses experiences. Eur J Oncol Nurs 15: 382-389.

23. Munck B, Fridlund B, Mårtensson J (2008) Next-of-kin caregivers in palliative home care--from control to loss of control. J Adv Nurs 64: 578-586.

24. Billings JA (2011) The end-of-life family meeting in intensive care part II: Familycentered decision making. J Palliat Med 14: 1051-1057.

25. Kagawa-Singer, M (2011) Impact of Culture on Health Outcomes. J Pediatr Hematol Oncol 33: 90-95.

26. Sepúlveda C, Marlin A, Yoshida T, Ullrich A (2002) Palliative Care: the World Health Organization's global perspective. J Pain Symptom Manage 24: 91-96. 